Abstracta Iranica Abstracta Iranica

Revue bibliographique pour le domaine irano-aryen

Volume 40-41 | 2019

Comptes rendus des publications de 2017-2018

\title{
Raimund Schulz. "Over the water and across the Desert - Trans-Saharan Contacts of the Mediterranean World in the 6th and 5th Century BC"
}

\section{Astrid Nunn}

\section{OpenEdition}

\section{Journals}

Édition électronique

URL : http://journals.openedition.org/abstractairanica/48164

DOI : 10.4000/abstractairanica.48164

ISBN : 1961-960X

ISSN : 1961-960X

Éditeur :

CNRS (UMR 7528 Mondes iraniens et indiens), Éditions de l'IFRI

\section{Référence électronique}

Astrid Nunn, « Raimund Schulz. "Over the water and across the Desert - Trans-Saharan Contacts of the Mediterranean World in the 6th and 5th Century BC" », Abstracta Iranica [En ligne], Volume 40-41 | 2019, document 10, mis en ligne le 15 juillet 2019, consulté le 24 avril 2021. URL : http:// journals.openedition.org/abstractairanica/48164; DOI : https://doi.org/10.4000/abstractairanica. 48164

Ce document a été généré automatiquement le 24 avril 2021

Tous droits réservés 


\title{
Raimund Schulz. "Over the water and across the Desert - Trans- Saharan Contacts of the Mediterranean World in the 6th and 5th Century BC"
}

\author{
Astrid Nunn
}

\section{RÉFÉRENCE}

Raimund Schulz. "Over the water and across the Desert - Trans-Saharan Contacts of the Mediterranean World in the 6th and 5th Century BC", Journal of Ancient Civilizations,

Changchun, vol. 32/2, 2017, p. 147-174

1 L'Afrique était dans l'esprit des Grecs et des Romains moins liée à une richesse incommensurable que les régions de l'est - de la Méditerranée à l'Inde. Ceci n'empêcha pas les Grecs de s'intéresser du moins au nord de ce continent. Ils furent relayés par les Phéniciens et les Puniques qui circumnaviguaient souvent autour de l'Afrique de l'ouest et dont le périple le plus connu est celui de Hanno. Indéniablement plus ardues étaient les expéditions à l'intérieur des terres. L'A. reconstitue la route possible des tribus de Nasamons, évoquées par Hérodote, qui partant de la Lybie pourrait avoir traversé le Sahara et atteint Tombouctou Timbuctu (Mali). Les richesses naturelles étaient attrayantes mais le manque de structures politiques stables ont fait que cette partie de l'Afrique ne fut vraiment exploitée qu'à partir du XVI ème $s$. 


\section{AUTEURS}

\section{ASTRID NUNN}

Université de Munich 